\title{
Teori Behavior dalam Meningkatkan Motivasi Hafalan Surat Pendek Al-Quran
}

\author{
Marlina* \\ Jurusan Bimbingan dan Konseling Islam, UIN Sunan Gunung Djati, Bandung \\ *Email:marlinara2@gmail.com
}

\begin{abstract}
ABSTRAK
Penelitian ini mengungkapkantentang proses, hasil dan faktor-faktor yang mempengaruhi dari pelaksanaan teori behavior dengan teknik reward dalam meningkatkan motivasi hafalan surat pendek Al-Quran pada kelas B di Taman Kanak-Kanak Al-Quran (TKA) Darussalam. Metode yang digunakan dalam penelitian ini adalah metode deskriptif dengan menggunakan pendekatan kualitatif. Teknik pengumpulan data dilakukan melalui observasi, wawancara langsung kepala sekolah dengan guru kelas, dan dokumentasi, dengan menggunakan analisis reduksi data, penyajian data dan penyimpulan akhir (verifikasi).Hasil yang didapat dalam penelitian ini menunjukkan bahwa pemberian reward yang dilakukan oleh guru kelas kepada siswanya dalam meningkatkan motivasi hafalan surat pendek Al-Quran pada anak di TKA Darussalam Pameungpeuk, memiliki hasil yang efektif dan sangat berpengaruh dalam meningkatkan motivasi hafalan anak-anak. Reward yang diberikan oleh pembimbing/guru yaitu, reward verbal reward non-verbal.
\end{abstract}

Kata Kunci: TeoriBehavior, Reward, Motivasi, Hafalan Al-Quran

\section{ABSTRACT}

This research reveals the processes, outcomes and factors that influence from the implementation of behavioral theory with reward techniques in improving the motivation of memorizing the Quran short letter to class B in Kondergarten Al-Quran Darussalam. The method used in this research is descriptive method by using qualitative approach. Data collection techniques are done through observation, principal direct interview with classroom teacher, and documentation, using data reduction analysis, data presentation and final conclusion (verivication). The results obtained in this study indicate that the giving of rewards by classroom teachers to their students in improving the motivation of memorizing the Quran short letter to the child in TKA Darussalam Pameungpenk, has effective results and very influential in improving the 
Marlina

motivation of rote children. Reward provided by the supervisor/ teacher is reward verbal and reward non-verbal.

Keywords:BehaviorTheory, Reward, Motivation, Memorize Quran

\section{PENDAHULUAN}

Anak merupakan amanah (titipan) dari Allah SWT yang diberikan kepada siapa saja yang dikehendaki-Nya. Kapanpun dan dimanapun, juga sesuai dengan keinginan-Nya. Begitu pula Allah SWT kuasa untuk tidak memberikan anak kepada siapa saja yang dikehendaki-Nya, sesuai dengan takdir dan hikmah yang terkandung di balik itu. Amanah itu tentu harus dijaga dan dipelihara secara berkesinambungan, dalam bentuk pendidikan dan pengajaran yang benar terutama dalam mengajarkan Al-Quran pada anak-anak. Mengajarkan Al-Quran pada anak sedini mungkin merupakan fondasi utama untuk mencetak anak-anak muslim yang kokoh berpegang pada kitab suci, tumbuh dewasa sesuai fitrahnya. Sehingga akan terpancar cahaya-cahaya terang dihati mereka, sebelum hawa nafsu menguasai serta mengotori hati mereka.

Para sahabat Rasulullah SAW memahami dengan baik peran penting menghafal Al-Quran dan pengaruhnya dalam jiwa anak. Oleh karena itu, mereka tekun sekali mengajarkan Al-Quran kepada anak-anak mereka, sebagai bentuk pengamalan petunjuk yang diberikan oleh Rasulullah saw. Diriwayatkan dari Mush'ab bin Sa'd bin Abi Waqaash r.a., dari ayahnya, dia berkata bahwa Rasulullah saw. pernah bersabda,

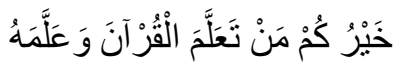

"Sebaik-baiknya kalian adalah orang yang mau belajar Al-Quran dan mau mengajarkannya”. (H.R. Ahmad)

Mempelajari Al-Quran bermakna sebagai upaya internal individu untuk melakukan perbaikan pribadi. Sedangkan mengajarkan Al-Quran bermakna sebagai upaya perbaikan eksternal dan memiliki nilai dakwah yang wajib dilakukan terhadap sesama muslim. Dengan demikian individu yang mempelajari Al-Quran diberikan banyak keistimewaan sekaligus tanggung jawab untuk menyebarkan apa yang dipelajari kepada orang lain melalui jalan dakwah (Sa'dulloh, 2008: 9).

Adapun keutamaan membaca dan menghafal Al-Qur'an adalah individu yang mengamalkannya akan menjadi sebaik-baiknya manusia, dinaikkan derajatnya oleh Allah, Al-Qur'an akan memberi syafa'at kepada orang yang membacanya, Allah menjanjikan akan memberikan orangtua yang anaknya menghafalkan al-qur'an sebuah mahkota yang bersinar (pahala yang luar biasa), hati orang yang membaca al-qur'an akan senantiasa dibentengi dari siksaan, hati 
mereka menjadi tentram dan tenang, serta dijauhkan dari penyakit kepikunan.

Menghafal Al-Qur'an bukanlah pekerjaan yang mudah, akan tetapi bukan pula suatu hal yang tidak mungkin, walaupun demikian telah banyak orang yang hafal Al-Qur'an namun banyak pula yang tidak hafal Al-Qur'an. Menghafal AlQuran merupakan suatu kegiatan yang mengikut sertakan aktivitas ingatan di dalamnya. Maka dari sangat perlu menanamkan dan menumbuhkan kecintaan anak pada Al-Quran sejak dini, karena menurut pakar Psikologi, daya ingat pada masa anak-anak sangatlah kuat.

Dalam proses hafalan tersebut diperlukannya rangsangan motivasi sebagai pemberi semangat agar anak merasa senang. Ada berbagai cara untuk menumbuhkan motivasi pada anak-anak, diantaranya dengan pemberian reward. Reward merupakan satu rangkaian yang dihubungkan dengan dorongan atau dukungan yang dimiliki oleh paham teori behavior. Dengan adanya dorongan, perbuatan atau tingkah laku seseorang akan dan semakin menguat, sebaliknya dengan tidak adanya dorongan maka tingkah laku seseorang akan melemah (Sumanto, 2006: 117). Teori behavior menerangkan bahwa seseorang akan mengulang aktivitasnya apabila aktivitas serupa yang dilakukan sebelumnya mendapatkan hasil yang menyenangkan. Dalam hal ini Throndike mempertegas bahwa kesenangan itu akan memperkuat hubungan antara stimulus yang diberkan dan respons yang diinginkan (Syah, 2003: 43).

Dalam Al-Quran dijelaskan bahwa reward menunjukkan balasan terhadap apa yang diperbuat oleh seseorang di kehidupan dunia ini maka nanti di akhirat akan mendapat balasannya sesuai dengan apa yang telah dikerjakan.

Allah berfirman dalam Al-Qur'an QS Fushilat ayat 46:

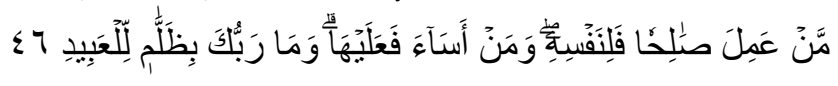

Artinya: "Barangsiapa yang mengerjakan amal yang saleh maka (pabalanya) untuk dirinya sendiri dan barangsiapa mengerjakan perbuatan jabat, maka (dosanya) untuk dirinya sendiri; dan sekali-kali tidaklah Rabb-mu menganiaya hamba-hamba-Nya" (Depag RI, 2006: 482).

Peranan reward dalam proses pengajaran cukup penting, terutama sebagai faktor eksternal dalam mempengaruhi tingkah laku belajar anak. Hal ini berdasarkan atas berbagai pertimbangan logis, diantaranya reward dapat menimbulkan motivasi belajar anak dan memiliki pengaruh yang positif dalam kehidupan anak.

Penggunaan teknik reward dalam meningkatkan motivasi sama dengan yang digunakan di TKA Darussalam dalam proses kegiatan hafalan surat pendek AlQuran pada anak. Kegiatan hafalan quran ini terjadwal pada hari senin sampai 
dengan selasa pagi, yaitu sebelum melaksanakan pembelajaran yang lainnya. Pada pembelajaran tersebut beberapa anak diperintahkan maju ke depan untuk melafalkan hafalan surat pendek yang telah dihafalkan. Jika ada anak yang mampu menghafalnya secara baik dan benar, maka guru akan memberikan reward atau penghargaan kepada anak tersebut. Hal ini dilakukan agar anak merasa senang dan bangga terhadap prestasinya dalam menghafal Al-Quran. Sehingga diharapkan anak tersebut dapat terus meningkatkan hafalannya. Maka di sini peranan guru atau pembimbing sebagai motivator sangat penting karena dapat merangsang dan memberikan dorongan terhadap potensi anak.

Hasil dari penelusuran yang dilakukan, terdapat hasil penelitian terdahulu yang membahas mengenai "Terapi Behavior dengan Teknik Reward dan Punishment dalam Meningkatkan Disiplin Diri Anak Usia Prasekolah Kelas TK A RA Darul Hafidhin Wonocolo Surabaya". Hasil penelitian menyatakan bahwa setelah diterapkannya terapi behavior dengan tehnik reward dan punishment, para siswa yang memiliki disiplin diri yang rendah mulai berubah sedikit demi sedikit. Para siswa sudah banyak yang tidak datang terlambat lagi, sudah tidak asyik bermain sendiri atau dengan temannya, mulai mendengarkan dan memperhatikan apa yang disampaikan oleh guru, sudah tidak banyak yang membuat keramaian saat pembelajaran berlangsung meskipun harus sering diberikan hukuman berupa teguran, ancaman maupun peringatan untuk mengingatkan mereka dan membuat mereka diam (Purnama, 2017).

Adapun penelitian yang dilakukan oleh Fitriyani \& Ratnani (2016) ditemukan bahwa siswa yang mendapatkan penerapan Mystery Motivator selama pelajaran Agama Islam mengalami peningkatan motivasinya menghafal surat pendek Al-Qur'an, dimana siswa yang mendapatkan mystery motivator mengalami peningkatan motivasi yang signifikan dalam menghafal surat pendek Al-Qur'an dibandingkan dengan siswa yang tidak mendapatkan Mystery Motivator. Selanjutnya penelitian yang dilakukan oleh Hidayah (2016) diungkapkan bahwa metode tahfidz Al-Qur'an untuk anak usia dini di antaranya adalah metode talqin, membaca mushaf, dan mendengarkan murrotal. Selanjutnya penelitian yang dilakukan oleh Hijiriyanti (2018) diungkapkan bahwa Hasil yang diperoleh setelah melakukan penelitian ini adalah sebagai pembimbing, usaha yang dilakukan yaitu: membantu santri ketika kesulitan dalam menyetorkan hapalan Al Qur'an, memperhatikan problem yang dihadapi santri dalam menghapal Al-Qur'an, dan memberi saran.

Persamaan dari penelitian ini dengan penelitian sebelumnya ialah samasama menggunakan pendekatan metode deskriptif dengan pendekatan kualitatif. Kemudian perbedaan dari penelitian terdahulu dengan penelitian ini adalah fokus yang di telitinya tidak sama dan lokasi penelitian penulis lakukan di Tanam Kanak-Kanak Al-Quran (TKA) Darussalam Sekeawi Kecamatan Pameungpeuk 
Kabupaten Bandung dan judul penelitiannya pun berbeda.

Dari latar belakang diatas, maka permasalahan yang dirumuskan dalam penelitian ini meliputi Bagaimana proses pelaksanaan teori behavior dengan teknik reward dalam meningkatkan motivasi hafalan surat pendek Al-Quran? Bagaimana hasil dari pelaksanaan teori behavior dengan teknik reward dalam meningkatkan motivasi hafalan surat pendek Al-Quran? Faktor-faktor apa yang mempengaruhi teori behavior dengan teknik reward dalam meningkatkan motivasi hafalan surat pendek Al-Quran pada kelas B di Taman Kanak-Kanak Al-Quran (TKA) Darussalam?

Metode yang digunakan dalam penelitian ini adalah metode deskriptif dengan menggunakan pendekatan kualitatif. Teknik pengumpulan data dilakukan melalui observasi, wawancara langsung kepala sekolah dengan guru kelas, dan dokumentasi, dengan menggunakan analisis reduksi data, penyajian data dan penyimpulan akhir (verifikasi).

\section{LANDASAN TEORITIS}

Teori yang dijadikan landasan dalam penelitian ini adalah teoribehavior dengan teknik reward dalam meningkatkan motivasi hafalan surat pendek AlQuran.Teori behavior merupakan teori perkembangan prilaku, yang dapat diukur, diamati dan dihasilkan oleh respon pelajar terhadap rangsangan. Adapun menurut Sofiyan Willis (2004: 69):

"Dasar teori behavior adalah bahwa perilaku dapat dipahami sebagai hasil kombinasi: (1) belajar waktu lalu dalam hubungannya dengan keadaan serupa, (2) keadaan motivasional sekarang dari efeknya terhadap kepekaan lingkungan, dan (3) perbedaan-perbedaan biologik baik secara genetik atau karena gangguan fisiologis".

Pendekatan tingkah laku atau behavior menekankan pada dimensi kognitif individu dan menawarkan berbagai metode yang berorientasi pada tindakan (action-oriented) untuk membantu mengambil langkah yang jelas dalam mengubah perilaku. Teori behavior memiliki asumsi dasar bahwa setiap tingkah laku dapat dipelajari, tingkah laku lama dapat diganti dengan tingkah laku yang baru, dan manusia memiliki potensi berperilaku baik atau buruk, tepat atau salah. Selain itu, manusia dipandang sebagai individu yang mampu melakukan refleksi atas tingkah lakunya sendir, mengatur serta dapat mengontrol perilakunya, dan dapat belajar tingkah laku baru atau dapat mempengaruhi perilaku orang lain (Komalasari, 2011: 141).

Behavior menitik beratkan pada perilaku individu. Perilaku individu ada karena adanya stimulus (rangsangan eksternal). Reaksinya berupa gerak dan 
perubahan jasmani yang bisa diamati secara objektif, serta bisa dipelajari dari luar. Manusia dikatakan sebagai makhluk kebiasaan belaka sehingga dia bisa dijadikan sedemikian rupa, dengan jalan memberi perangsang perangsang yang tepat, sehingga ada proses belajar dan berlatih. Banyak teknik yang dimiliki oleh paham behavioral dalam menangani permasalahan yang dihadapi, salah satunya yaitu menggunakan teknik pemberian reward.

Dalam kamus bahasa inggris, reward diartikan dengan ganjaran, hadiah atau perhargaan. Menurut Amir Dien Indrakusuma,reward adalah penilaian yang bersifat positif terhadap belajarnya siswa. Sedangkan menurut Purwanto reward (ganjaran) adalah alat untuk mendidik anak-anak supaya anak-anak dapat merasa senang karena perbuatan atau pekerjaanya mendapat penghargaan (Purwanto, 2006: 182). Substansi reward sebenarnya adalah sebuah bentuk respons seseorang karena perbuatannya. Dalam Al-Quran dijelaskan bahwa reward menunjukkan balasan terhadap apa yang diperbuat oleh seseorang di kehidupan dunia ini maka nanti di akhirat akan mendapat balasannya sesuai dengan apa yang telah dikerjakan. Allah berfirman dalam Al-Quran surat Fushilat ayat 46:

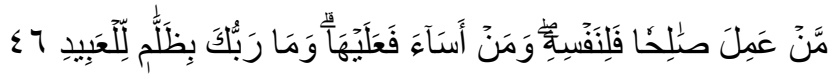

Artinya: "Barangsiapa yang mengerjakan amal yang saleh maka (pabalanya) untuke dirinya sendiri dan barangsiapa mengerjakan perbuatan jahat, maka (dosanya) untuk dirinya sendiri; dan sekali-kali tidaklab Rabb-mu menganiaya hamba-bamba-Nya" (Depag RI, 2006: 384).

Peranan reward dalam proses pengajaran cukup penting, terutama sebagai faktor eksternal dalam mempengaruhi tingkah laku belajar siswa. Hal ini berdasarkan atas berbagai pertimbangan logis, diantaranya reward dapat menimbulkan motivasi belajar siswa dan memiliki pengaruh yang positif dalam kehidupan siswa.

Reward (ganjaran) yang diberikan kepada anak-anak bentuknya bermacammacam, diantaranya:pertama, pujian. Pujian adalah satu bentuk reward yang paling mudah dilakukan. Pujian dapat berupa kata-kata seperti: baik, bagus, bagus sekali, kamu hebat, dan lain sebagainya. Dapat juga berupa kata-kata yang bersifat sugesti, misalnya: "Nah, lain kali akan lebih baik lagi".Kedua, penghormatan. Reward yang berupa penghormatan ini dapat berbentuk semacam penobatan, yaitu anak yang mendapatkan prestasi yang bagus maka diumumkan dan ditampilkan dihadapan teman-temannya atau dihadapan orang banyak.Ketiga, hadiah. Yang dimaksud dengan hadiah di sini adalah reward yang berbentuk pemberian yang berupa barang. Reward seperti ini juga disebut reward materil, yaitu hadiah yang berupa barang seperti alat-alat keperluan sekolah seperti tas, buku, pensil, penggaris, penghapus dan sebagainya (Dahar, 2011: 20). 
Berdasarkan pemaparan di atas, teori bebavior dengan teknik reward dapat diterapkan dalam proses atau upaya meningkatkan motivasi anak khususnya dalam menghafal Al-Quran. Motivasi dalam Kamus Konseling (Sudarsono, 1997:149) berasal dari kata "Motivate" yang berarti mendorong, merangsang, menyebabkan, memberikan dorongan untuk berbuat yang didasarkan pada tindakan sebagai dorongan atau memenuhi kebutuhan.

Menurut Mc Donald, yang dikutif oleh Sardiman (2006: 73) bahwa motivasi "merupakan perubahan energi dalam diri seseorang yang di tandai dengan 'feeling' dengan di dahului tanggapan terhadap suatu tujuan." Dari batasan ini di dalamnya terdapat tiga unsur yang berkenaan dengan motivasi, yaitu: (1) Motivasi itu senantiasa mengawali terjadinya suatu perbuatan energi pada diri setiap individu; (2) Motivasi itu senantiasa dirangsang karena adanya suatu tujuan. Dalam hal ini motivasi sebenarnya merupakan suatu respon dari suatu aksi. Motivasi muncul dari dalam diri manusia, tetapi kemunculannya terangsang oleh suatu unsur lain, yakni tujuan, dantujuan ini akan menyangkut soal kebutuhan. Motivasi ditandai dengan munculnya rasa atau feeling dan efeksi seseorang. Dalam hal ini motivasi identik dengan persoalan-persoalan kejiwaan yang dapat menetukan tingkah laku manusia.

Dalam kamus besar bahasa Indonesia, hafalan berasal dari kata dasar hafal, yaitu mengingat sesuatu dengan mudah dan mengucapkannya di luar kepala. Sedangkan surah pendek adalah surah dalam Al-Quran yang tercantum pada juz ke 30, yang terdiri atas 37 surat. Dimulai dari surat ke 78 yaitu surat An-Naba hingga surat ke 114 yaitu surat An-Naas.

Al-Qur'an menurut bahasa adalah bentuk masdar dari qoro'a artinya bacaan, berbicara tentang apa yang tertulis dan padanya melihat dan menelaah. Menurut istilah, Al-Qur'an adalah kalam Allah yang diwahyukan kepada nabi Muhammad SAW sebagai mukzizat setiap suratnya dan membacanya ibadah. Allah berfirman dalam al-Qur'an Surah al-Hijr ayat 9 yang berbunyi:

\section{9}

Artinya: "Sesunggubnya Kami-lab yang menurunkan Al Quran, dan sesunggubnya Kami benar-benar memeliharanya" (Depag RI, 2006: 209).

Al-Qur'an merupakan satu-satunya kitab suci di muka bumi ini yang terjaga, baik secara lafadz dan isinya. Sebagaimana ayat diatas, hal ini merupakan janji Allah SWT yang akan selalu menjagannya sampai hari kiamat. Salah satu penjagaan Allah terhadap al-Qur'an adalah dengan memuliakan para penghafalnya.

Para ulama sepakat bahwa hukum menghafal al-Qur'an adalah fardhu 
kifayah. Apabila diantara anggota masyarakat ada yang sudah melaksanakannya maka bebaslah beban anggota masyarakat yang lainnya, tetapi jika tidak ada sama sekali, maka berdosalah semuanya. Prinsip fardhu kifayah ini dimaksudkan untuk menjaga al-Qur'an dari pemalsuan, perubahan, dan pergantian seperti yang pernah terjadi pada kitab-kitab yang lain pada masa lalu (Sa'dulloh, 2008: 1).

Dalam menghafal Al-Qur'an, motivasi menjadi dasar yang amat penting untuk pencapaian keberhasilan tujuan dan efektifitas kegiatan dalam proses menghafal. Teknik menghafal hanya memudahkan untuk mengingat informasi, tetapi motivasi adalah prasyarat mutlak untuk keberhasilan ini.

\section{HASIL DAN PEMBAHASAN}

Berdasarkan letak geografis, Kecamatan Pameungpeuk terletak di sebelah Timur ibu kota Kabupaten Bandung (Soreang) dengan jarak $\pm 8 \mathrm{KM}$ dan berada disebelah Selatan Ibu kota Provinsi Jawa Barat dengan jarak \pm 20 KM. Kecamatan ini mempunyai luas wilayah $1.399 .925 \mathrm{Ha}$, terdiri dari 6 desa, 24 dusun, 75 Rukun Warga (RW), dan 310 Rukun Tetangga (RT). Sekeawi merupakan salah satu daerah yang ada di desa Rancamulya kecamatan Pameungpeuk. Di mana lokasi tersebut masih belum ada sekolah berbasis Islam. Atas dasar kesadaran membantu masyarakat kurang mampu untuk bersekolah, sekaligus menciptakan sekolah yang berbasis islami, dan sekaligus memberikan kesadaran terhadap masyarakat bahwa betapa pentingnya pendidikan untuk putra-putrinya. Maka pada tahun 2005 berdirilah sembuah lembaga pendidikan yaitu pondok pesantren Darussalam yang dimana di dalamnya ituterdapat pendidikan Taman Kanak-Kanak Al-Quran (TKA) dan Taman Pendidikan AlQuran (TPA).

Taman kanak-kanak/ taman pendidikan Al-Quran Darussalam merupakan lembaga pendidikan luar sekolah yang menitik beratkan pengajaran pada pembelajaran membaca Al-Quran dengan muatan tambahan yang berorientasi pada pembentukan akhlak dan kepribadian islamiah yang dikelola secara profesional. TKA Darussalam ini beralamat di Kp. Sekeawi RT 01 RW 01 Desa Rancamulya Kecamatan Pameungpeuk Kabupaten Bandung

Hasil penelitian ini menemukan hasil motivasi anak-anakdalam menghafal surat pendek Al-Qurandimulai dari proses menghafal surat pendek Al-Quran dan pemberian reward, hasil dari pemberian reward dalam meningkatkan motivasi hafalan dan faktor-faktor yang mempengaruhi dari pelaksanaan teori behavior dengan teknik reward dalam meningkatkan motivasi hafalan surat pendek AlQuran pada kelas B di Taman Kanak-Kanak Al-Quran (TKA) Darussalam.

\section{Pelaksanaan Teknik Reward dalam Meningkatkan Motivasi Hafalan Surat Pendek Al-Quran}


Pelaksanaan hafalan melalui teknik reward dalam meningkatkan motivasi hafalan surat pendek Al-Quran pada kelas B di TKA Darussalam dengan melihat unsurunsur bimbingan, yaitu pertama pembimbing (Guru). Jumlah pembimbing/guru yang ada di TKA Darussalam berjumlah empat orang, yakni Ibu Lina, Ibu Ani Maryani, Ibu Tita Rosita, dan Ibu Yeni Puspita. Ibu Ani dan Ibu Tita sebagai pembimbing/guru di Kelas A, sedangkan ibu Yeni dan Ibu Lina pembimbing/guru di kelas B. Ibu Yeni sebagai pembimbing/guru utama dalam proses belajar mengajar di kelas B tersebut. Sedangkan ibu Lina sebagai guru kedua yang membantu dalam proses belajar mengajar seperti, storan membaca iqro. Ibu Yeni sebagai guru utama di kelas B lulusan dari STAI (Sekolah Tinggi Agama Islam) Yamisa Soreang dengan jurusan PAI (Pendidikan Agama Islam). Pembimbing memiliki keahlian di bidang Ilmu Al-Quran, sehingga mampu membimbing anak dalam proses menghafal $\mathrm{Al}$-Quran sesuai dengan ketentuanketentuan dalam membaca Al-Quran. Selain itu juga, sebagai seorang pembimbing, bu Yeni memiliki kualifikasi yang baik sebagai seorang pembimbing, yaitu dari segi nafsiyah, jasadiah dan ijtimaiah.

Kedua,terbimbing (Peserta Didik), jumlah peserta didik di TKA Darussalam kelas B berjumlah 23 anak, yang terdiri dari 7 laki-laki 16 perempuan, yang keseluruhannya dijadikan sebagai objek penelitian. Mayoritas dari mereka telah memiliki hafalan Al-Quran seperti surat-surat pendek AlQuran (Al-Ikhlas, Al-Falaq, An-Nas, Al-Ashr, Al-Fatihah) ketika mereka belajar di kelas A. Namun dalam jumlah hafalan surat yang di hafal ada perbedaan antara anak yang satu dengan anak yang lainnya. Hal ini karena kemampuan pribadi yang dimiliki oleh setiap anak berbeda-beda, terlihat dari kemampuan anak dalam menghafal Al-Quran dan jumlah surat yang telah mereka hafal.

Ketiga,metode. Ada beberapa metode yang dilakukan oleh guru di TKA Darussalam dalam proses menghafal Al-Quran yaitu sebagai berikutrumah (Wawancara dengan Ibu Yeni pada tanggal 21 Februari 2018):

“(1) Metode Sima'i. Yang dimaksud dengan metode ini ialah anak-anak mendengarkan suatu bacaan yang dilafalkan oleh seorang pembimbing untuk dihafalkannya. Setelah itu, diikuti oleh anak-anak secara bersamasama; (2) Metode muroja'ah, seorang anak mengulang kembali hafalanhafalan yang telah dihafalkan sebelumnya, yang ditugaskan oleh guru; (3) Sambung ayat, guru atau pembimbing memberikan kuis atau soal mengenai ayat-ayat yang sudah dihafal terhadap anak-anak muridnya; (4) Menugaskan anak menghafal di”.

Untuk meningkatkan motivasi anak-anak dalam menghafal surat-surat pendek Al-Quran tersebut, guru atau pembimbing di TKA menggunakan teknik pemberian reward. Ketika anak mampu menghafal surat-surat pendek yang telah 
ditugaskan maka guru atau pembimbing akan memberinya reward. Dengan diberikannya reward tersebut diharapkan mampu meningkatkan motivasi anakanak dalam menghafalkan surat-surat pendek Al-Quran.

Namun, sebelum memberikan reward guru kelas merencanakannya terlebih dahulu, agar pemberian teknik ini berjalan sesuai dengan apa yang diharapkan. Berikut ini pernyataan dari hasil wawancara dengan informan mengenai perencanaan pemberian reward tersebut Wawancara dengan Ibu Yeni pada tanggal 21 Februari 2018).

"Menurutnya, perencanaan pembelajaran hafalan surat pendek Al-Quran dengan menggunakan teknik reward dalam meningkatkan motivasi menghafal anak sangat penting untuk dilakukan. Karena itu dengan adanya pemberian reward (ganjaran) kepada peserta didik yang dapat meningkatkan motivasi hafalan surat pendek Al-Quran dapat mewujudkan efektifitas dalam proses pelaksanaan hafalannya"

Bentuk reward yang diberikan oleh guru atau pembimbing di TKA Darussalam ada dua macam, yaitu verbal dan non-verbal.

Pertama, Reward Verbal yaitu (i) pujian, pujian yang diberikan oleh guru/pembimbing kepada anak yaitu berupa ucapan seperti: anak hebat, good, bagus, pintar, dan alhamdulillah. Pemberian pujian ini diberikan saat anak dapat melakukan suatu hal yang sesuai dengan goals yang diharapkan oleh guru/pembimbing. Menurutnya, tabiat anak-anak umumnya ingin dipuji dan dihormati sehingga mereka merasakan bahwa Al-Quran telah memberi banyak manfaat dan membuatnya mencapai kedudukan yang baik di mata banyak orang. Perasaan seperti ini akan selalu ada dalam diri anak, khusunya saat usia kanakkanak. Pada usia ini anak-anak memang cenderung melihat atau menyukai sesuatu atas dasar manfaat yang diperolehnya. (ii) Mendoakan dalam bentuk memotivasi anak misalnya dengan mengatakan "semoga menjadi anak yang sholeh/ soleha, semoga masa depanmu cemerlang dan lain sebagainya.

Kedua, Reward non verbal. Bentuk-bentuk reward non verbal yaitu, (i) Mimik wajah, Saat memberikan reward/ penghargaan guru tersebut melakukannya dengan mimik wajah berseri disertai senyum, karena anak mampu melakukan suatu hal sesuai dengan yang guru harapkan. Sedangkan untuk gerakan badan guru/pembimbing tersebut mengikuti dari apa yang beliau lakukan saat itu. Ketika, guru mengatakan good, hebat, pintar maka diikuti dengan acungan ibu jari yang menunjukkan bahwa anak tersebut sudah melakukan hal yang bagus. (ii) Menepuk Pundak. Ketika anak ada yang berani maju ke depan diperintah ataupun tanpa diperintahkan, guru tersebut terkadang menepuk pundak anak sembari memberikan pujian. Hal ini dilakukan oleh guru/pembimbing untuk memberi motivasi dan lebih mengakrabkan antara peserta didik dan guru. (iii) 
Tanda Penghargaan; memberikan bintang penghargaan untuk dikumpulkan di star pocket yang ada di kelasanak (Wawancara dengan Ibu Yeni pada tanggal 21 Februari 2018).

Reward non verbal berupa pemberian bintang penghargaan yang kemudian dikumpulkan di star pocket kelas yang kemudian untuk beberapa minggu akan dihitung jumlah bintang dari masing-masing anak dan yang memiliki bintang terbanyak akan mendapatkan hadiah dari guru kelas. (iv) Piagam atau surat peghargaan. Menurut guru kelas, hadiah penghargaan ini hanya diberikan di akhir semester. Pemberian piagam penghargaan kepada anak ini merupakan wujud apresiasi yang diberikan sekolah atas segala potensi yang dimiliki oleh peserta didik di TKA Darussalam ini. Hal ini sesuai dengan pendapat Emmer (dalam Suharsimi Arikunto, 2002: 160-166): yang menyebutkan bahwa hadiah dalam bentuk penghargaan dapat diwujudkan dalam berbagai hal yang mempunyai arti "perhatian" seperti surat penghargaan atau piagam yang diberikan pada akhir semester.

Keempat,materi.Materi yang disampaikan oleh pembimbing dalam proses hafalan ini yaitu: (1) menggunakan semboyan-semboyan yang baik yang isinya mampu memacu rasa cinta anak kepada Al-Quran; (2) Menyebutkan nama surat dalam Al-Quran dan artinya; (3) Jumlah ayat dari surat-surat pendek dalam AlQuran; (4) Memberikan penjelasan mengenai arti dari ayat yang dibaca; (5) Menceritakan kisah-kisah yang ada di dalam Al-Quran; (6) Keistimewaan Para Penghafal Al-Quran; (7) Besarnya pahala yang akan diterima oleh para penghafal Al-Quran; (8) Memberikan mahkota bagi orangtuanya pada hari kiamat.Kelima, media.Media yang digunakan dalam pelaksanaan teknik reward ini, yaitu Juz. Ama; alat-alat tulis (Pensil, Penghapus, buku); bintang; Start Pocket (wadah bintang); buku absen; dan data hafalan anak (Wawancara dengan Ibu Yeni pada tanggal 21 Februari 2018).

\section{Hasil Teknik Reward dalam Meningkatkan Motivasi Hafalan Surat Pendek Al-Quran}

Berikut ini adalah pernyataan dari guru kelas mengenai hasil dari pemberian reward pada motivasi hafalan surat pendek Al-Quran.

"Pertama, setelah diberikan penghargaan anak-anak sangat merasa senang hal ini terlihat dari bahasa tubuhnya seperti kegiarangan sambil bilang "hore, asyik, dll", anak lebih bersemangat dalam menghafal setelah diberikan penghargaan, dan pemberian penghargaan dapat meningkatkan motivasi hafalan anak. Kedua, dengan memberikan reward ini membuat anak semakin antusias dan terkadang suka berebutan ingin menujukan hafalannya di depan kelas. Ketiga, hasil pemberian reward pada motivasi 
hafalan anak juga diamati melalui observasi dengan melakukan pengukuran motivasi hafalan anak setiap hari yang kemudian diakumulasikan setiap minggunya".

Sehingga dapat diperoleh data tentang perkembangan motivasi hafalan surat pendek Al-Quran pada anak sebagai berikut ini:

Tabel 3.4

Contoh jadwal mingguan

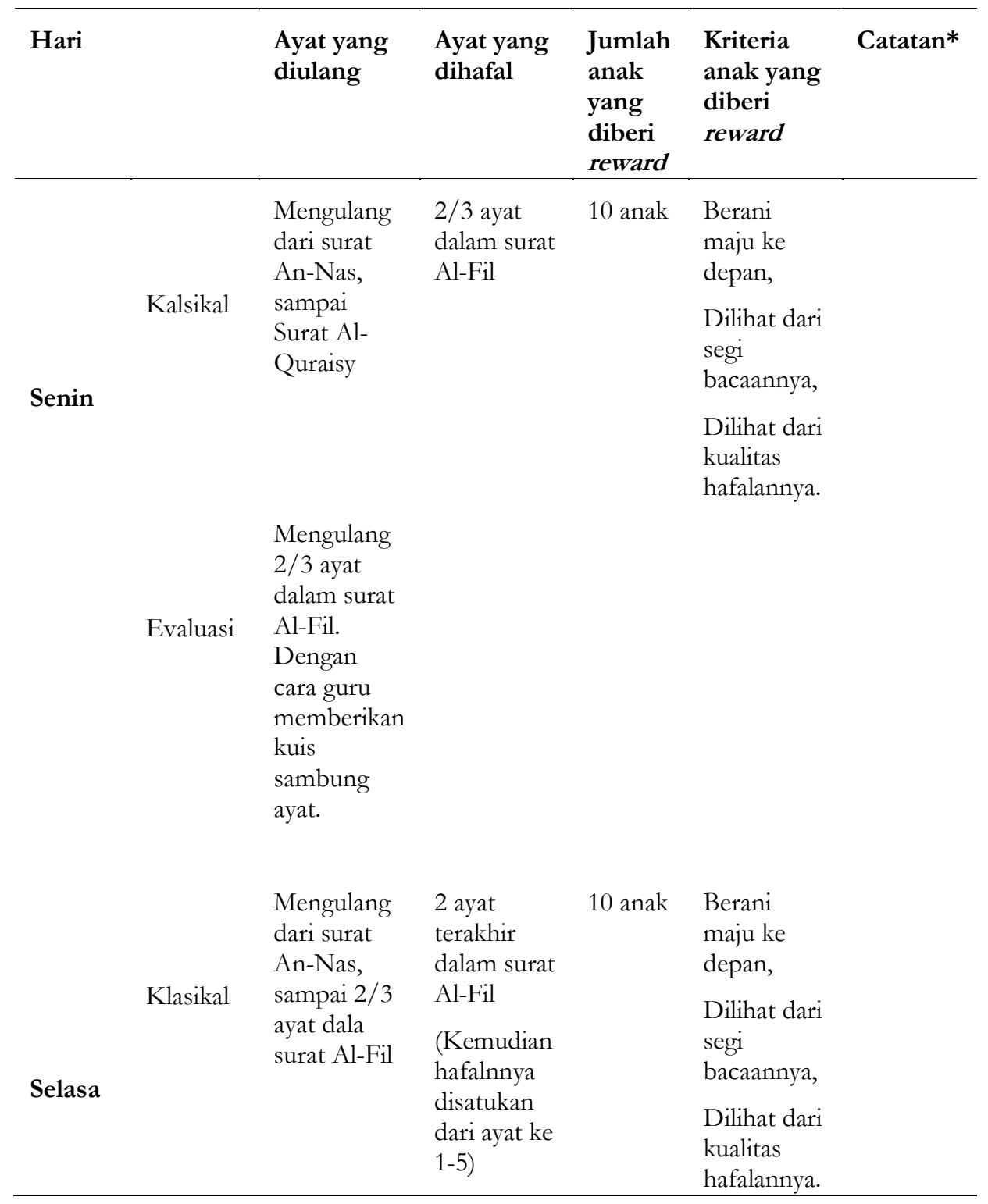




$\begin{array}{ll} & \text { Satu surat } \\ \text { Evaluasi } & \text { Al-Fil. } \\ & \text { Dengan } \\ & \text { cara guru } \\ \text { memberikan } \\ \text { kuis } \\ \text { sambung } \\ \text { ayat }\end{array}$

(Sumber: wawancara dengan Ibu Yeni pada tanggal 13 Maret 2018)

*Catatan

Dari sepuluh anak bentuk reward yang diberikan bermacam-macam yaitu reward verbal dan non-verbal. Reward verbal (pujian dan doa) dan non-verbal (mimik wajah, menepuk pundak) dilakukan oleh guru kepada setiap anak yang berani maju ke depan diperintah atau tanpa diperintah dengan melafalkan hafalannya, karena reward jenis ini dilakukannya secara spontan. Anak-anak yang mendapatkan reward berupa bintang setiap harinya rata-rata tujuh atau delapan anak. Ciri-ciri yang diberikan bintang ini yaitu anak yang berani maju ke depan, bacaannya benar dan hafalannya lancar. Jika ada anak yang telah berani maju ke depan tetapi hafalan yang dimilikinya kurang lancar, maka guru tetap memberikan reward atau ganjaran dalam bentuk nyata. Namun, bentuk rewardnya berbeda dari anak yang lancar hafalan Al-Qurannya. Hal ini diberikan oleh guru untuk menghargai bentuk usaha dan keberanian anak karena telah maju ke depan melafalkan hafalannya meskipun belum hafal betul.

Dari setiap pertemuan yang sering mendapatkan reward ada 3 anak yaitu Hilmi dan Keisya dan Reyhan. Mereka anaknya pintar, dilihat dari segi hafalannya serta mudah mengingat dan menangkap intruksi yang diberikan oleh guru. Selain itu juga mereka yang selalu jadi juara kelas dari mulai kelas A sampai semester I kelas B.

Tabel 3.5

Jadwal Bulanan

\begin{tabular}{ll}
\hline Minggu & Target Hafalan \\
\hline Pertama & Hafal 2 atau 3 ayat (untuk surat yang panjang) \\
Kedua & Hafal satu surah (lanjut dari minggu pertama) \\
Ketiga & Hafal beberapa ayat \\
Keempat & Hafal 2 Surah \\
\hline
\end{tabular}

Sumber: (hasil wawancara dengan ibu Yeni pada tanggal 13 Maret 2018)

Irsyad : Jurnal Bimbingan, Penyuluhan, Konseling, dan Psikoterapi Islam 6(4)(2018) 413-432 
Tabel 3.6

Hasil dari target hafalan bulanan

\begin{tabular}{|c|c|c|}
\hline \multirow[t]{2}{*}{ Nama } & \multicolumn{2}{|l|}{ Jumlah Hafalan } \\
\hline & Sebelum & Sesudah \\
\hline Alifah Istiqomah & An-Nas s.d. An-Nasr & An-Nas s.d At-Al-Fil \\
\hline Adelia Puspita & An-Nas s.d. Al-Kafirun & An-Nas s.d At-Takasur \\
\hline Akmaludin & An-Nas s.d. Al-Kautsar & An-Nas s.d Al-Qoriah \\
\hline Aulia Izzatunnisa & An-Nas s.d. Al-Kautsar & An-Nas s.d Al-Qoriah \\
\hline Dava Sopian & An-Nas s.d. Al-Kafirun & An-Nas s.d At-Takasur \\
\hline Diyana & An-Nas s.d. Al-Kautsar & An-Nas s.d At-Takasur \\
\hline Haniy Fauziyah & An-Nas s.d. Al-Kafirun & An-Nas s.d Al-Qoriah \\
\hline Intan Nur Alfiyah & An-Nas s.d. Al-Lahab & An-Nas s.d Al-Fil \\
\hline Imas Rahmawati & An-Nas s.d. Al-Kautsar & An-Nas s.d Al-Qoriah \\
\hline $\begin{array}{l}\text { Keisya Nabila } \\
\text { Anatasya }\end{array}$ & An-Nas s.d. Al-Kautsar & An-Nas s.d Al-Qoriah \\
\hline M. Faiz Hilmi & An-Nas s.d. Al-Kautsar & An-Nas s.d Al-Qoriah \\
\hline Mineu Hasanah & An-Nas s.d. Al-Kafirun & An-Nas s.d At-Takasur \\
\hline Nenden Nasyila & An-Nas s.d. Al-Kautsar & An-Nas s.d Al-Qoriah \\
\hline Nizam Zulfiyansah & An-Nas s.d. Al-Kautsar & An-Nas s.d Al-Qoriah \\
\hline Raisya Sabela & An-Nas s.d. Al-Kautsar & An-Nas s.d At-Takasur \\
\hline $\begin{array}{l}\text { Syifa Nurul } \\
\text { Fatimah }\end{array}$ & An-Nas s.d. Al-Kautsar & An-Nas s.d Al-Qoriah \\
\hline $\begin{array}{l}\text { Syakira Khairun } \\
\text { Nisa }\end{array}$ & An-Nas s.d. Al-Kafirun & An-Nas s.d Al-Qoriah \\
\hline Syifa Tania & An-Nas s.d. An-Nasr & An-Nas s.d Al-Fil \\
\hline Rika Indriyani & An-Nas s.d. Al-Kautsar & An-Nas s.d At-Takasur \\
\hline M. Reyhan Albira & An-Nas s.d. Al-Kafirun & An-Nas s.d At-Takasur \\
\hline
\end{tabular}

Sumber: Wawancara dan Dokumentasi

Berdasarkan data yang diperoleh dari jumlah 23 anak yang ada di TKA tersebut, anak yang termotivasi ada 20 orang hal ini terlihat dari target hafalannya. Meskipun tidak semua hafalannya sama rata antara anak satu dengan anak yang lainnya. Hal ini merupakan pencapaian yang sangat besar, karena ketika anak mulai masuk ke TKA ini ada anak yang sama sekali belum hafal surat-surat pendek Al-Quran. Mengenai perbedaan jumlah hafalan surat pendek 
yang telah dihafal oleh peserta didik kelas B di TKA Darussalam, hal ini dikarenakan kemampuan masing-masing anak berbeda-beda dan ada juga anak yang benar-benar baru masuk sekolah, langsung masuk ke kelas B (Alifah, Intan dan Syifa), masih belum dapat membaca dan menghapal huruf Arab secara aktif. Mereka tidak seperti siswa yang sebelumnya pernah mengikuti pendidikan di kelas A di sekolah yang sama.

Selain itu juga ada tiga orang anak yang tidak termotivasi, yaitu:

Tabel 3.7

Anak yang tidak termotivasi

\begin{tabular}{lll}
\hline & \multicolumn{2}{l}{ Jumlah Hafalan } \\
\cline { 2 - 3 } Nama & Sebelum & Sesudah \\
Goestomi & An- Nas s.d An-Nashr & An-Nas s.d Al- Maun \\
Regina & An-Nas s.d Al-Lahab & An-Nas- Al-Kautsar \\
M. Arya & An-Nas s.d An-Nashr & An-Nas - Al- Maun \\
\hline
\end{tabular}

Sumber: wawancara dan dokumentasi

Mereka bertiga tidak termotivasi dengan alasaan yang berbeda-beda antara satu dengan yang lainnya (Wawancara dengan Ibu Yeni pada tanggal 21 Februari 2018):

"Perama, Goestomi orang tuanya sibuk bekerja, sehingga kalau ada tugas terkadang jarang mengerjakan. Selain itu juga dia anaknya jahil, nakal, di kelas suka bikin gaduh, dan jarang masuk sekolah. Padahal sebenarnya dia anaknya pintar. Kalau saja dapat perhatian dari orang tuanya, karena kalau hanya mengandalakan guru di sekolah saja tidak cukup. Kedua, Regina kalau diperhatikan di kelas anaknya itu pendiam, pemalu, tidak ceria, kurang bersosialisasi, dan kalau bicara suaranya pelan. Ketiga, M. Arya anaknya jahil, dan jarang masuk sekolah".

\section{Faktor-Faktor yang Mempengaruhi}

Jika berbica mengenai faktor-faktor yang mempengaruhi suatu hal, tentunya tidak terlepas dari faktor pendukung dan faktor penghambat yang dihadapi hal tersebut. Hal ini pun terdapat dalam proses teknik reward dalam meningkatkan motivasi hafalan surat pendek Al-Quran pada kelas B di TKA Darussalam. Berdasarkan hasil wawancara dengan guru yang memberikan pengajaran tersebut, diperoleh beberapa informasi dan pemaparan mengenai faktor-faktor tersebut, yaitu faktor pendukung dan faktor penghambat.

Pertama, faktor pendukung ada dua yaitu faktor intern dan faktor ekstern. Faktor intern yaitu: (1) Timbulnya niat yang ikhlas dan semangat pada diri anak 
untuk menghafal Al-Quran; (2) Anak mengulang hafalan yang telah dilakukan sebelum melanjutkan hafalan selanjutnya; (3) Anak optimis akan berhasil menghafal Al-Quran; (4) Anak memiliki rasa percaya diri; (5) Anak mengetahui keutamaan menghafal Al-Quran.

Sedangkan faktor ekstern yaitu: (1) Adanya tanggung jawab dan kedisiplinan dari guru atau pembimbing; (2) Adanya kesabaran dari pembimbing; (3) Memberikan pengalaman lebih nyata. Pemberian reward merupakan hal yang nyata, dan membuat anak semakin bersemangat dalam proses menghafal, sebagai mana yang diungkapkan oleh guru kelas:

"Pemberian reward berpengaruh pada proses hafalan, anak cenderung bersemangat yang intinya mereka bersaing untuk menjadi yang terbaik" (Hasil wawancara dengan Ibu Yeni).

Terkait dengan motivasi anak bahwa yang menjadi motivasi anak dalam menghafal Al-Quran ada beberapa faktor yang mempengaruhinya, yaitu faktor internal dan eksternal. Yang termasuk faktor intrinsik/ internal yaitu keinginan anak yang timbul atau dorongan dalam dirinya untuk menghafal Al-Quran. Dan yang termasuk faktor ekstrinsik/eksternal yaitu anak terdorong keinginanya oleh faktor luar yaitu orang tua, guru, lingkungan akademik, dan juga penghargaan dari orang sekitar. Di mana anak menghafal Al-Quran itu supaya kelak orang tuanya bahagia dan dapat hadiah mahkota dari anaknya yang hafal Al-Quran. Selain itu juga di tunjang dengan metode yang di gunakan dalam menghafal AlQura untuk membantu proses menghafalnya.

Faktor tersebut sesuai dengan yang dijelaskan oleh Sardiman (2016: 89), bahwasanya motivasi belajar terbagi dua macam, yaitu; motivasi intrinsik dan motivasi ekstrinsik. Pertama,Motivasi intrinsik adalah motivasi yang timbul karena adanya rasa bangga akan kemampuan diri (Marlina, 2010: 257). Rasa bangga terhadap kemampuan diri inilah yang disebut penghargaan intrinsik (Adhim, 2006: 24).Motivasi intrinsik memiliki tujuan menjadi orang yang terdidik, yang berpengetahuan, yang ahli dalam bidang studi tertentu. Satusatunya jalan untuk menuju ke tujuan yang ingin dicapai ialah belajar, tanpa belajar tidak mungkin mendapat pengetahuan, tidak mungkin menjadi ahli. Jadi, motivasi ini muncul dari kesadaran diri sendiri dengan tujuan secara esensial, bukan sekedar simbol dan seremonial. Bila seseorang telah memiliki motivasi intrinsik dalam dirinya, maka ia secara sadar akan melakukan suatu kegiatan yang tidak memerlukan motivasi dari luar dirinya.

Dalam aktifitas menghafal, motivasi intrinsik sangat diperlukan. Seseorang yang tidak memiliki motivasi sulit sekali melakukan aktifitas belajar menghafal secara terus menerus. Seseorang yang memiliki motivasi intrinsik selalu ingin maju dan belajar. Keinginan itu dilatar belakangi oleh pemikiran yang positif, 
bahwa semua mata pelajaran yang dipelajari sekarang akan dibutuhkan dan sangat berguna kini dan dimasa mendatang. Kedua, motivasi ekstrinsik.Motivasi ekstrinsik ini adalah hal dan keadaan yang datang dari luar individu siswa yang juga mendorongnya untuk melakukan kegiatan belajar, pujian dan hadiah (reward), peraturan atau tata tertib sekolah, suri tauladan guru, orang tua, merupakan contok konkret motivasi yang dapat mendorong siswa untuk belajar. Adapun menurut Suryabrata (1993:72):

"Motivasi ekstrinsik adalah dorongan untuk mencapai tujuan-tujuan yang terletak diluar perbuatan, serta motif-motif yang berfungsinya karena adanya rangsangan dari luar. Seperti; orang tua, guru, teman atau sahabat".

Dalam hal ini, dari pengertian motivasi tersebut bahwasanya motivasi intrinsik anak ialah dorongan dari dalam diri anak ingin menghafal Al-Quran. Sedangkan yang terkait dalam motivasi ekstrinsik dalam motivasi anak-anak di TKA Darussalam yaitu dengan menggunakan pemberian reward.

Kedua, faktor penghambat. Setiap aktivitas yang dilakukan tentu tidak terlepas dari suatu kendala atau hambatan, termasuk dalam proses hafalan tersebut. Berikut ini adalah pernyataan dari guru atau pembimbing mengenai kendala atau hambatan yang dihadapi selama membimbing dalam pencapaian target hafalan anak dan hambatan dalam memberikan reward diantaranya ada faktor intern dan faktor ekstern. Faktor intern yaitu: (1) Adanya kejenuhan anakanak ketika menghafal surat atau ayat. Ketika proses hafalan berlangsung kadang mereka mengikuti, kadang tidak; (2) Konsentrasi anak. Perhatiannya mudah terpecah ke hal yang lain; (3) Kehadiran anak, karena yang malas sekolah otomatis ia akan tertinggal hafalannya meskipun nanti ada pengulangan; (4) Anak tidak senantiasa mengikuti dan mengulang-ulang hafalannya. Sedangkan faktor ekstern yaitu: (1) Kurangnya kerjasama dari orang tua. Ketika anak diberi tugas untuk dihafalkan di rumah, ada beberapa anak yang tidak menghafalkannya. Hal ini tentu dengan berbagai alasan, diantaranya karena oarang tua yang sibuk bekerja, jadi tidak ada waktu buat membimbing atau menemani anaknya untuk menghafal. Maka anak pun merasa enggan untuk menghafalnya.

Tabel 3.8

Anak yang terhambat oleh orang tua

\begin{tabular}{lll}
\hline Nama & Jumlah Hafalan & Keterangan \\
\hline Goestomi & An-Nas- Al- Maun & Orang tua sibuk bekerja \\
Regina & An-Nas- Al-Kautsar & Orang tua sibuk bekerja \\
M. Arya & An-Nas - Al- Maun & Orang tua sibuk bekerja \\
\hline
\end{tabular}

Irsyad : Jurnal Bimbingan, Penyuluhan, Konseling, dan Psikoterapi Islam 6(4)(2018) 413-432 
Sumber: hasil wawancara dengan Ibu Yeni

(2) Pengeluaran untuk pemberian penghargaan berupa benda seperti, pensil dan penghapus dibeli dengan uang pribadi sehingga tidak dapat dilakukan secara terus menerus. Terkadang ada anak yang tidak melakukan suatu hal atau pekerjaan dengan baik namun tetap meminta penghargaan berupa bintang atau stempel; (3) Semua berebut ingin mendapatkan hadiah. Ketika ada anak yang diberikan hadiah atau reward, maka anak-anak yang lainpun terkadang merengek minta hadiah atau reward tersebut; (4) Beberapa anak pasti akan menanyakan hadiah yang akan diperoleh nantinya dan adapula yang akan tetap menginginkan penghargaan meskipun tidak bersikap baik ataupun memenuhi goal yang diharapkan.

\section{PENUTUP}

Dari hasil penelitian yang telah dilaksanakan oleh peneliti yang berlokasi di Taman Kanak-Kanak Al-Quran (TKA) Darussalam Sekeawi Desa Rancamulya Kecamatan Pameungpeuk Kabupaten Bandung mengenai Teori Behavior dengan Teknik Reward dalam Meningkatkan Motivasi Hafalan Surat Pendek Al-Quran pada usia 4-6 Tahun, maka dari itu peneliti dapat menarik beberapa simpulan sebagai berikut. Pertama, pelaksanaan teknik reward dalam meningkatkan motivasi hafalan surat pendek Al-Quran ini dilakukan dua hari dalam seminggu yaitu pada hari senin sampai dengan hari selasa. Dalam pelaksanaan hafalan Al-Quran tidak terlepas dari unsur-unsur bimbingan yaitu, ada pembimbing/guru, terbimbing (peserta didik), metode, materi dan media. Metode yang digunakan oleh pembimbing/guru dalam proses hafalan surat pendek Al-Quran yaitu dengan menggunakan metode sima'I (mendengar), muraja'ah, sambung ayat dan menugaskan kembali menghafal di rumah. Namun untuk meningkatkan motivasi anak dalam menghafal surat-surat pendek Al-Quran, guru/pembimbing menggunakan teknik reward.

Pemberian reward yang dilakukan di TKA Darussalam terdiri dari dua macam yaitu, reward verbal dan reward non-verbal. Reward verbal ini berupa pujian (seperti hebat; bagus; pintar; good; dan lain sebagainya) dan mendoakan. Sedangkan reward non-verbal yang diberikan adalah dalam bentuk gestural (berupa, senyuman; tepuk tangan; anggukan; acungan jempol dan menepuk pundak), dalam bentuk tanda penghargaan (bintang, cap stempel, piagam penghargaan), dan berupa benda (buku, pensil, penghapus). Pemberian reward ini dilakukan oleh guru/pembimbing segera setelah respon dari peserta didik muncul yakni ketika anak telah mampu menghafal surat pendek Al-Quran dengan baik, benar dan lancar.

Kedua, hasil dari penerapan teknik reward dalam meningkatkan motivasi 
hafalan surat pendek Al-Quran yang telah diterapkan di TKA Darussalam ini, anak-anak sangat merasa senang hal ini terlihat dari bahasa tubuhnya seperti kegiarangan sambil bilang "hore, asyik, dll", anak lebih bersemangat dalam menghafal setelah diberikan penghargaan. Selain itu juga dengan memberikan reward ini membuat anak semakin antusias dan terkadang suka berebutan ingin menujukan hafalannya di depan kelas. Hal ini menunjukan bahwa dengan diberikannya reward mampu meningkatkan motivasi anak dalam menghafal surat pendek Al-Quran. Dari jumlah 23 siswa yang ada di TKA Darussalam tersebut, yang termotivasi dengan adanya reward tersebut berjumlah 20 anak.

Ketiga, faktor-faktor yang mempengaruhinya ada dua, yaitu faktor pendukung dan fakor penghambat. Faktor pendukung yaitu timbulnya niat yang ikhlas dan semangat dari diri anak, anak memiliki rasa percaya diri, anak optimis akan berhasil menghafal Al-Quran, adanya tanggung jawab, kedisiplinan, dan kesabaran dari guru atau pembimbing. Sedangkan faktor penghambatnya yaitu, adanya kejenuhan anak-anak ketika menghafal surat atau ayat; konsentrasi anak; kehadiran anak; kurangnya kerjasama dari orang tua; dan pengeluaran untuk pemberian penghargaan berupa benda seperti; pensil dan penghapus dibeli dengan uang pribadi; semua berebut ingin mendapatkan hadiah; dan ada beberapa anak yang menanyakan hadiah apa yang akan diperoleh. Saran bagi peneliti lain yaitu diharapkan dapat memperluas dengan subjek yang lebih besar lagi dan dengan latar belakang serta dengan permasalahan yang berbeda.

\section{DAFTAR PUSTAKA}

Arikunto, Suharsimi. (2002). Prosedur Penelitian Suatu Pendekatan Praktek. Jakarta: Rineka Cipta.

Dahar, Ratna Willis. 2011. Teori-Teori Belajar dan Pembelajaran. Jakarta: Erlangga.

Departemen Agama Republik Indonesia. (2006). Al-Quran dan Terjemahnya.Bandung: CV Diponegoro.

Fitriyani, E. \& Ratnani, I. P. (2016). Memotivasi Siswa Menghafal Surat Pendek Al-Qur'an Melalui “Mystery Motivator” dalam Jurnal Psikologi 12(1).

Hidayah, A. (2017). Metode Tahfidz Al-Qur'an Untuk Anak Usia Dini dalam Jurnal Studi Ilmu-Ilmu al-Qur'an dan Hadis 18(1).

Hijriyanti, T. (2018). Peranan Pembimbing dalam Meningkatkan Hapalan Al-

Qur'an Santri dalam Irsyad: Jurnal Bimbingan, Penyuluban, Konseling, dan Psikoterapi Islam 6(3).

Komalasari, Kokom. (2011). Pembelajaran Kontekstual: Konsep dan Aplikasi. Bandung: Refika Aditama.

Marlina, Elly. (2012). Motivasi Berpuasa Ramadhan dan Moralitas Remaja.Ilmu Dakwah: Academic Journal for Homiletic StudiesVol. 6 No. 2

Purwanto, Ngalim. (2006). Ilmu Pendidikan Teoritis dan Praktis. Bandung: Remaja 
Karya.

Rizki Purnama (2017) dari Fakultas Dakwah dan Komunikasi Universitas Islam

Negeri (UIN) Sunan Ampel Surabaya dengan judul "Terapi Behavior dengan Teknik Reward dan Punishment dalam Meningkatkan Disiplin Diri Anak Usia Prasekolah Kelas TK A RA Darul Hafidhin Wonocolo Surabaya".

Sa’dullah. (2008). 9 Cara Cepat Menghafal Al-Quran. Jakarta: Gema Insani.

Sanjaya, Wina. (2009). Penelitian Tindakan Kelas. Jakarta: Kencana.

Sardiman. (2006.)Interaksi dan motivasi Belajar Mengajar. Jakarta: PT Grafindo Persada.

Sumanto, Wasty. (2006). Psikologi Pendidikan: Landasan Kerja Pemimpin Pendidikan. Jakarta: PT Rineka Cipta.

Suryabrata, Sumadi. (1993). Psikologi Pendidikan. Jakarta: PT Raja Grafindo. Syah, Muhibbin. (2003). Psikologi Belajar. Jakarta: PT Raja Grafindo Persada.

Willis, Sofyan S. (2014). Konseling Individual Teori dan Praktek. Bandung: Alfabeta. 